\title{
TTR
}

Traduction, terminologie, re?daction

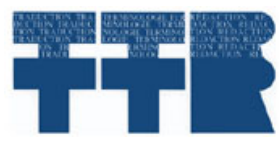

\section{Altered States: Translation and Minority Languages}

\section{Michael Cronin}

Volume 8, numéro 1, 1er semestre 1995

Orientations européennes en traductologie

URI : https://id.erudit.org/iderudit/037198ar

DOI : https://doi.org/10.7202/037198ar

Aller au sommaire du numéro

\section{Éditeur(s)}

Association canadienne de traductologie

\section{ISSN}

0835-8443 (imprimé)

1708-2188 (numérique)

Découvrir la revue

\section{Citer cet article}

Cronin, M. (1995). Altered States: Translation and Minority Languages. TTR, 8(1), 85-103. https://doi.org/10.7202/037198ar

\begin{abstract}
Résumé de l'article
"États altérés »: traduction et langues minoritaires —La complexité linguistique de l'Europe est souvent passée sous silence dans les commentaires politiques sur les activités en traduction. En particulier, on fait abstraction de l'expérience historique et du destin contemporain des langues minoritaires d'Europe quand on évalue quelles sont les stratégies de traduction à la disposition des locuteurs de ces langues minoritaires. Le problème provient en partie de ce que l'on ne pense pas à définir de façon créative les langues minoritaires dans un contexte de traduction. Ce contexte comprend la dimension des nouvelles technologies qui peuvent aboutir à un nouveau classement des langues, en Europe et ailleurs. Le rôle de la traduction dans le cas d'une langue minoritaire d'Europe, le gaélique irlandais, est abordé sous l'angle des dilemmes auxquels font face les langues moins utilisées. La traduction est à la fois bienvenue et crainte. Les choix qui s'offrent aux traducteurs de langues minoritaires diffèrent considérablement de ceux qui s'offrent aux traducteurs de langues majoritaires. Il importe d'accorder une attention plus grande qu'actuellement à ces différences dans le discours théoriques sur la traduction des langues minoritaires. En outre, la traductologie en tant que discipline ne réfléchit que rarement sur les préjugés de sa propre langue majoritaire intégrée aux structures de diffusion disciplinaires du savoir. Non seulement les langues minoritaires sont essentielles à la diversité sur laquelle repose le fragile écosystème de la culture humaine mais elles soulèvent des questions qui sont au coeur de la traductologie en tant que domaine de recherche.
\end{abstract}

Tous droits réservés @ TTR: traduction, terminologie, rédaction - Les auteurs, Ce document est protégé par la loi sur le droit d'auteur. L’utilisation des 1995 services d'Érudit (y compris la reproduction) est assujettie à sa politique d'utilisation que vous pouvez consulter en ligne.

https://apropos.erudit.org/fr/usagers/politique-dutilisation/ 


\section{Altered States: Translation and Minority Languages}

\section{Michael Cronin}

\section{Perspective}

\subsection{Post-colonial Criticism}

Tejaswini Niranjana (1992) sees the problematic of translation in the post-colonial context as "a significant site for raising questions of representation, power and historicity. The context is one of contesting and contested stories attempting to account for, to recount the asymmetry and inequality of relations between peoples, races, languages" (Niranjana, 1992, p. 1). Niranjana further argues that "my concern is to probe the absence, lack or repression of an awareness of asymmetry and historicity in several kinds of writing on translation" (p. 9). Siting Translation, however, bears eloquent testimony to the continued operation of the ahistoricity, exclusion and essentialism it so deplores in conventional translation theories and colonial narratives. Throughout the study references are repeatedly made to "European languages" (p. 164), "European descriptions" (p. 166), European attitudes, narratives and values. There is no attempt made to "account for the asymmetry and inequality of relations between peoples, races, languages" in Europe itself. The history of the evolving power relationships between the many languages in Europe is ignored and we are presented with the ahistorical, essentialist concept of "Europe" with its implicitly homogenous translation strategies. The signal failure to account for 
the linguistic and translational complexity of Europe in part stems from the tendency by post-colonial critics to reduce Europe to two languages, English and French and to two countries, England and France. Thus, the critique of imperialism becomes itself imperialist in ignoring or marginalising the historical and translation experience of most European languages. When Eric Cheyfitz (1991) refers to "Europeans" and their need to feel that New World languages were "virtually a lack of language" (Cheyfitz, 1991, p. 164), one could argue that he is merely using a convenient form of geographical shorthand in that the colonial powers in the New World were all from Europe. The convenience is achieved at a cost. Those European countries or languages that were not involved in the colonial enterprise become synonymous with the very "lack of language" attributed to the indigenous inhabitants of the New World.

\subsection{Definition of Minority Languages}

The reductionism and partiality that are implicit in essentialist accounts of the European translation experience are all the more regrettable in that minority languages in Europe offer graphic illustrations of the processes of conquest, resistance and selfdefinition that guide translation in its relationship with power and history. Before examining in greater detail the position of one such minority language, Irish Gaelic, it is useful to specify what exactly is meant here by a minority language. The concept of "minority" with respect to language is dynamic rather than static. "Minority" is the expression of a relation not an essence. The relations can assume two forms: diachronic and spatial. The diachronic relation that defines a minority language is an historical experience that destabilises the linguistic relations in one country so that languages find themselves in an asymmetrical relationship. In the case of Ireland, English was a minority language for centuries (Seymour, 1929). The ascendancy of the English language did not begin until the sixteenth and seventeenth century with Tudor and Cromwellian expansionist policies which sought not only the military but also the cultural and linguistic submission of the native Irish (Leersen, 1986, p. 292). Military, social and economic forces, notably the Great Famine of the 1840 s where Ireland lost half its mainly Irish- 
speaking population through starvation and emigration (Kallen, 1993, pp. 100-114), led to the erosion of the Irish language and the massive language-shift to English in the nineteenth-century (de Freine). Therefore, the position of the language changed from majority to minority status as a result of political developments over time.

The spatial relationship is intimately bound up with diachronic relationships but it is important to make a distinction between those languages that find themselves in a minority position because of a redrawing of national boundaries and those which occupy the same territory but are no longer in a dominant position such as Irish. Russian has now become a minority language in most of the Baltic Republics with the break-up of the Soviet Union. The change in borders left Russian speakers outside the State where Russian is the majority language. The spatial/diachronic distinction is useful in evaluating the radically different contexts in which minority languages operate from the perspective of translation. Languages that derive their minority status from spatial realignments find themselves in close proximity to countries where the language has majority status. Thus, in terms of opportunities for translators, publishing outlets for translations, readers for translated works and the proper development of translation studies, the situation is markedly different from the position of languages whose status is diachronically determined and do not have a larger linguistic hinterland that provides a source of patronage notion for translation activity.

The Celtic languages on the European periphery (Breton, Welsh, Irish and Scots Gaelic) have traditionally suffered from this problem though efforts have been made, particularly in Wales and Ireland to develop indigenous systems of patronage. It is important to stress the relational dynamic of minority languages if only to underline the significance of minority languages to translation theory and practice. This significance is related to three factors. Firstly, languages and political circumstances change. The majority status of a language is determined by political, economic and cultural forces that are rarely static and therefore all languages are potentially 
minority languages. It follows that the historical experience of a minority language can offer useful insights into the translation fate of majority languages should contexts change.

Secondly, translation relationships are based on figure/ ground oppositions. Languages can be divided into those languages which are target-language intensive and those languages which are source-language intensive. An example of a TL intensive language would be English where there is intense translation activity from English into other languages but where there is markedly less translation traffic in the opposite direction (Jacquemond, 1992, pp. 139-140). A SL intensive language would be almost any minority language where translations are largely from other source languages that enjoy majority status. Thus, the consideration of the translation practice or theory of English, French, German, Russian translators, for example, must be relational and analysed from the minority as well as the majority perspective. The concepts of asymmetry and hierarchy that motivate the following comments by Jacquemond must be applied not only to North-South translation processes but also as I have indicated above to Europe itself:

Because translation theory $[. .$.$] has developed on the basis of the$ European linguistic and cultural experience, it relies on the implicit postulate of an egalitarian relationship between different linguistic and cultural areas and has yet to integrate the recent results of the sociology of interculturality in the colonial and postcolonial contexts (Jacquemond, 1992, p. 140).

A third factor that informs the relational position of minority languages is the fact that it is precisely the pressure to translate that is a central rather than a peripheral aspect of experience. In this respect, for minority languages themselves it is crucial to understand the operation of the translation process itself as the continued existence of the language and the self-perception and self-confidence of its speakers are intimately bound up with translation effects. Translation theory should not therefore be seen as an esoteric luxury indulged in by the mandarins of major languages but as a crucial 
means to understanding the position of minority-language speakers in relationships of language and power.

\section{Irish Gaelic and the Paradoxes of Translation}

To attempt a survey of the translation policies of Europe's different minority languages is a task that requires several volumes not one article. However, we will attempt to examine a number of questions that relate to the situation of one specific language, that of Irish Gaelic, in order to highlight the problems and challenges facing any comprehensive theorisation of contemporary translation practice in Europe. Minority languages have a fundamentally paradoxical relationship with translation. As languages operating in a multilingual world with vastly accelerated information flows from dominant languages, they must translate continually in order to retain their viability and relevance as living languages. Yet, translation itself may in fact endanger the very specifity of those languages that practice it, particularly in situations of diglossia. The situation of translation in the culture of a minority language is therefore highly ambiguous. The ambiguity is partly related to the functions of translation in the minority language culture. The functions can be broadly divided into the pragmatic function and the aesthetic function (see section 3). The "pragmatic" function relates to those aspects of translation that relate to the routine, practical needs of the minority language. In Ireland, the pragmatic function primarily involves the translation of the proceedings and Acts of Parliament, the translation of official documentation and schoolbooks and the production of translated material for the Irishlanguage media (news reports, weather forecasts and so on). Responsibility for this function lies mainly with the translation section of the Irish Department of Education known as An Gúm and the translating and interpreting division of the Irish parliament known as Rannóg an Aistriúcháin (Cronin, 1993, pp. 80-83). Allied to the pragmatic function are the terminological requirements of the language which in Ireland are the responsibility of the terminological committee, An Coiste Téarmaiochta. 
The most notable feature of pragmatic translation is that it is overwhelmingly unidirectional. In the Irish case, the source language is almost exclusively English and the pragmatic relationship is markedly asymmetrical. Translation is necessary at one level to ensure that Irish speakers can live full lives in the language enjoying similar language rights to English speakers yet at another level the very condition of this existence is the translation fact with the attendant risks of massive source-language interference in asymmetrical contexts. This has the inevitable result that translation is not a marginal but a central activity in the development of the minority language. The task of the translator is to produce a reineSprache but in a sense that is radically different from that intended by Benjamin. The translator attempts to respect the linguistic integrity of the target language particularly at the levels of syntax and idiom (O'Leary, 1929, p. 85). In so doing, however, s/he is open to the charge of "purism," of the "ethnic cleansing" of language, of a commitment to atavistic, originary essentialism. Translators in minority languages are thus placed in a classical double bind. If they translate allowing the full otherness of the dominant language to emerge in the translation, inviting rather than eliminating anglicisms from their Irish translations, then the language into which they translate becomes less and less recognisable as a separate linguistic entity capable of future development and becomes instead a pallid imitation of the source language in translatorese. On the other hand, if they resist interference and opt for target-oriented communicative translations that domesticate the foreign text, the danger is one of complacent stasis. Translation no longer functions as an agent of regeneration in the target language.

The difficulty in debates on language and translation is avoiding what the Canadian sociologist Anthony Wilden calls "Freudian counter-insurgency." Wilden claims that Freud's Oedipal and paranoia theories ultimately blame the victims for their own plight and he extends the remit of his analysis to cover other theories that blame the oppressed for their own oppression (Wilden, 1980 , p. 148). Language relationships are asymmetrical. The powerless or those with less power will always appear to be on the 
"defensive" to those in power. The French, for example, were recently heavily caricatured in the Anglophone press for the provisions of the loi Toubon. A historical irony was that the charges of irredentism, passéisme and purism that were levelled against French legislators were precisely those that were advanced by defenders of France's coercive linguistic policies towards minority languages over the years. Speakers of minority languages find that their relationship to translation is immediately problematic and that their responses often run the risk of misrepresentation as ethnocentric chauvinism.

\title{
3. Minority Languages and Translation Resistance
}

In 1986 an anthology of poems by contemporary Irish-language poets was published with English translations. The anthology was called An Tonn Gheal/The Bright Wave and the editor Dermot Bolger explained the purpose of the anthology in the following terms:

\begin{abstract}
Although it was government policy after independence to translate as much as possible from English and European literature into Irish [...] no effort was made to reverse this process and make living Irish literature available in English. In fact, even when I was growing up and perhaps to some extent today, the idea of such translation was frowned upon, the general idea being that those who wished to know what was happening in Irish should be able to read the language in the first place and any concessions would dilute the chances of revival of the language (Bolger, 1986, p. 9).
\end{abstract}

An earlier anthology of translations from Irish An Duanaire: Poems of the Dispossessed published in 1981 had met with considerable success but the Bright Wave was different in that it published translated poems of contemporary poets. The anthology also started a vogue in poetic translation from Irish into English that has not diminished. This translation risorgimento was greatly facilitated by the change in the policy of the Irish Arts Council in 1984 with respect to translation. Through direct publication assistance and the author's royalty scheme the Arts Council made it easier for 
publishers to consider the publication of translations, previously unpopular due to the costs associated with translation (Cassidy, 1988, pp. 8-9; Cronin, 1990, p. 114). The translators and editors of translation anthologies defended their work on the grounds that the translations would bring the work of Irish-language poets to a wider audience. The English-language poets who were primarily involved in the translation work had much to learn from the work of their Irish-language peers and the latter had to be freed from the ghetto of linguistic isolationism. Translation was part liberatory, part evangelical. The acceptance of translation by many prominent poets in the Irish language could be seen as an endorsement of a policy of openness, delivering poets in a minority language from the invisibility of small readerships. However, the target language, English, was not innocent. In a situation of diglossia where the minority language is competing for the attentions of the same group of speakers, Irish people, then translation cannot be divorced from issues of power and cultural recuperation. A prominent contemporary poet in Irish, Biddy Jenkinson, refuses to have her work translated into English claiming, "I prefer not to be translated into English in Ireland. It is a small rude gesture to those that think that everything can be harvested and stored without loss in an English-speaking Ireland" (Jenkinson, 1991, p. 34).

Pól Ó Muirí an Irish-language poet and critic from Northern Ireland is more vehement in his denunciation of the cultural politics that he sees as animating the recent English-language translation initiatives:

My main contention, then, is that this new rapport between Irish poets of both languages, as expressed in these various anthologies is bogus. There is no real desire for an exchange of ideas. We are simply witnessing poets while away the dark winter nights by translating Irish poetry. It occurs to me that translation, in this instance, has a lot more to do with colonisation - a desire to scavenge rather than a desire to propagate. It is patronage and pity (O Muirí, 1993, p. 16).

The minority language, in O Muiri's eyes, is the object of the predatory attentions of English-language translators who strip the 
language of its possessions and contribute nothing to its continued survival and growth. The writer in the minority language can find that writing itself may become a form of pre-editing. As Barra ó Séaghdha has observed with respect to a much-translated Irish language poet, Nuala Ní Dhomhnaill:

A writer in a minority language who is in regular contact with translators, who appears indeed to regard translation as an inherent part of the translation process, is running a risk. Subconsciously, with no element of calculation, the degree of future translatability and the values of the English-language audience may become factors that penetrate and weaken the original impulse (ó Séaghdha, 1993, p. 144).

\section{Undertheorisation and Institutional Constraints}

An aspect of the English-Irish translation relationship that is neglected by polemicists is the question of undertheorisation. In the introduction to the Bright Wave anthology Dermot Bolger is economical in his description of the translation policy of the anthology:

In giving my instructions to translators, I have stressed that, for this book, I am more concerned that the spirit of the original poem should come across and work as effectively as possible, as against merely producing a strictly literal line for line version (Bolger, 1986, p. 9).

Declan Kiberd in a later anthology published in 1991 under the title An Crann faoi Bhláth makes no reference whatsoever to the existence of language difference or the inherent difficulty of the translator's task. Thus, the radically dissimilar lexical, syntactic and phonological structures of Irish are ignored as are questions of allusion, resonance and intertextuality. Failure to signal language difference and the nature of the translation process leads to the illusion of transparency and disguises the degree and kind of transformation involved in the shift from a Celtic to a Germanic language. Furthermore, the poetic traditions in both languages are markedly different presenting other problems for the translator. In 
Lawrence Venuti's terms the English-language translators are using "fluent strategies," obscuring difference through familiarity, sacrificing a sense of otherness to the reassurance of readability in the major language (Venuti, 1992, p. 5).

The absence of a critical, self-reflexive activity in the translation enterprise has a number of consequences. Firstly, the absence of commentary on the linguistic transformations conceals otherness in minority to major language translations but it leaves the minority language vulnerable to extensive interference in majority to minor language translations. Secondly, the lack of reflexion is not simply a question of language shift but also relates to the way in which major language culture is informed by the minority language in translation (e.g. in the area of song, modes of intention, semantic fields, national identity) and also how and in what way the minority language is being altered by the translation process. Thirdly, translation theory itself remains hostage to the perceptions and interests of major languages. Although Ireland has been an independent state for over seventy years, it is only in the last five years that a hesitant movement towards speculative inquiry in the area of translation has begun. Translation theory is not, however, a luxury that only major languages can afford. On the contrary, it is a vital necessity for minority languages in Europe and elsewhere that they understand in historical and contemporary terms the theoretical implications of inwards and outwards translation policies.

The undertheorisation that has been noted in the case of Irish is not confined to that language. Translation conferences are generally noteworthy for the lack of attention paid to minority languages and the dominance of theories predicated on the historical experience and insights of the translation triumvirate, English, French and German. The hegemony is partly understandable due to a structural problem that often inhibits contributions from practitioners of minority languages. The problem is one of exemplification. If one was to speak on the ludic uses of translation in the prose writings of a contemporary Irish Gaelic novelist, Séamas Mac Annaidh, it would be necessary to provide examples of how English informs Mac Annaidh's Gaelic and is then parodied to 
create a new hybrid language that energises the speech of his young, urban characters. Reading passages from his work to contextualise, for example, lexical choices would enlighten few but the reader and other speakers of Irish Gaelic who as a group do not generally figure prominently in translation studies conferences. So the obvious solution is to translate the passage into English but this is precisely the source-language that is being discussed and the aim of the analysis is to assess target-language effects. Another approach is to select brief examples and use periphrasis to explain the consequences of translation strategies in the minority TL. The ensuing descriptive burden does little for economy and completeness in presentation so that the translation scholar may find it easier to discuss in one of the lingua francas of international conferences, mainstream translation theories or works written in major languages.

There is an obvious constraint of language competence and the desire to be mutually intelligible that guides the organisation of international gatherings of translators but it is worth reflecting on the Babelian paradoxes of our own coming together. The wish to communicate with each other which more often than not leads to the adoption of English as the common language sets up a dynamic within the world of translation studies itself where the power relationships are uncommonly similar to those prevailing in other areas of economic and political activity on the planet today. Translation theory must address the question, therefore, of its own institutional translation. In other words, we need to consider more carefully in Europe and elsewhere how the fact of translating our research results and theoretical insights into the major languages (in the linguistic sense) of theoretical discourse circumscribes our field of inquiry or alters the reception and presentation of evidence.

\section{Minority Languages, Translation and Technology}

Minority languages have traditionally seen the translation task as relating primarily to printed matter and the provision of interpreting services. Hence, in post-Independence Ireland a considerable effort was made through translation schemes to provide reading material in Irish (Mac Niocláis, 1991, pp. 109-120). However, the minority 
status of language in the translation situation no longer arguably relates to the number of speakers and the existence of a publishing infrastructure but to the implantation of the language in technological developments. The analysis of a language with a view to its eventual uses in machine-readable form demand both the availability of the necessary resources and the political awareness of the intrinsic link between language development and modernisation. In the case of minority languages which are not dominant in their own national territory eg the Celtic languages, commitment to technological advance has a strategic importance. For speakers of majority languages, the tendency can be to view the minority language from an "antiquarian" perspective. The minority language is an heirloom, a relic from another distant, non-urban age spoken by peasants in picturesque surroundings (Ó Ciosáin, 1990, pp. 2327). In nineteenth century Ireland the translation strategies that frequently resulted from these antiquarian perspectives were Orientalist in their scholarly literalism (Ó Háinle, 1982, pp. 37-58). The proper approach to a dead or dying language was embalment. The original was to be preserved in the thermafrost of exegesis.

Thus, the involvement of minority languages with new technologies is not just a question of allowing its users to live a full life in that language in the late twentieth century but it also challenges the antiquarian illusion, the notion that somehow minority languages are unable to cope with the complexity of modern life and technology. The preliminary work that was carried out by the National Centre for Language Technology in Dublin to develop an Irish-language module for the Eurotra MT system, the development of an English-Irish module for the METAL MT system to deal with the automatic translation of official documentation, the production of on-line electronic dictionaries for Irish are initiatives that point to the potential for growth in the MATS and MT area (Cronin, 1993, pp. 16-18).

Technology is changing our definition of the minority language. The language of the software utilities, the compact discs, the documentation is generating what might be termed translation differentials. These differentials can be classified into two broad 
types, intralingual translation differentials and interlingual translation differentials. An example of an intralingual translation differential would be the relationship between British and American English. The grammar and spell checkers, the on-line dictionaries and thesauruses, the synthesised voices produced by sound cards in multimedia upgrade kits, the reference material in atlases and encyclopedias that can be accessed on compact discs like Microsoft Bookshelf are overwhelmingly North American in orientation. Reference material gives several on-screen pages to various US presidents but only two paragraphs to the European Community. The bulletin boards that can be accessed through the Internet are heavily dominated by American users as are the sites on the WorldWide Web. The translation takes place not only at the level of orthography and idiom but also at the level of intertextuality in view of the strong cultural bias in intertextual resources available either on CD's or on the Internet.

The interlingual translation differential is more apparent as languages other than English try to make software resources available to the non-Anglophone world. Software localisation is a significant growth area in translation but questions of intertextuality also need to be addressed if languages are not to find themselves with material that though translated reflects the cultural preoccupations and historical experiences of a different language and set of speakers. In the case of European languages like Irish that make extensive use of diacritics, using the Internet can be immensely tedious. The contributors to the Gaelic language bulletin board GAELIC-L, established in 1989, employ forward strokes to accent vowels. As any vowels can be accented in Irish, the result is that messages in Irish on the bulletin board are both difficult to read and awkward to produce. The convention of forward strokes is a small example of the pressures that are generated by a technology that is Anglophone in origin and takes little cognisance of language difference. Developments in informatics, multimedia, MT and the Internet have translation implications insofar as they create their own translation imperatives. The differentials mentioned above mean that a language's status is always provisional and that changes in technology, for example, can result in it becoming a minority 
language that is SL intensive as it imports more and more material into the language.

\section{Antiquarianism and Translation Choices}

The association of the Irish language with the past, a rural way of life, folklore has provided, as we have noted, an impetus for a visible commitment to new technology and forms of communication. However, the influence of stereotype on translation choice is formidable. The literature of modern Irish is practically non-existent in translations in languages other than English (Cronin, Mac Cóil \& Schneider, 1990). In English itself, the most widely available translations are those published in the Oxford University Press Classics series. The Islandman, Twenty-Years a Growing, Peig Sayers: An Old Woman's Reflections and Tis A Pity Youth doesn't Last are four titles that have been published in the series. All four books are set in remote islands of the West coast of Ireland. All four titles describe the experiences, customs and world-views of Irish speakers from another age. The translation choices conform to stereotypical views of the speakers of the Irish language in the English-speaking world and these views are in turn reinforced by such choices. Sherry Simon has noted in the case of FrenchCanadian literature that historically the tendency in English translations in Canada was to choose those texts that represented a non-urban, deeply religious Quebec, thus providing more comforting evidence that sustained stereotypical expectations (Simon, 1992, pp. 159-176).

It is not only the speakers of the major language that are affected by translation options. The speakers of minority languages can begin to internalise these representations and believe that an essential part of their being is constituted by these "imagotypes" (Leersen, 1986, pp. 445-455). The dominant languages in asymmetrical situations not only determine the specific representations of the minority SL culture but the translation selections also can also shape the literary history of a language. Alan Titley in a discussion of the literary fortunes of two twentieth- 
century writers in Irish, Seán Ó Ríordáin and Biddy Jenkinson claims:

There are no monoglot English-speakers with an understanding of Seán Ó Ríordáin because his work has never been available in translation. Other poets are now much better known and people writing in Irish constantly hear about them because we straddle both cultures and hear what the English-speaking media say about poets whose work has been translated. The fact that Biddy Jenkinson is not more widely read by the Irish-reading public is proof that the work is not the only criterion and that translation has a huge effect - a negative effect in the case of Jenkinson - on the public (Ó Cearnaigh, 1993, p. 66).

Titley here traces the effects of translation at the level of the minority-language reading public and at the level of external perceptions of the relative importance of particular writers in Irish this century. The effects of translation are both internal and external.

\section{Conclusion}

If the effects are seen as wholly baleful, then the future for translation theoreticians and practitioners in minority languages is indeed bleak. However, this would be to misrepresent the situation. As this article has attempted to demonstrate both the concept and reality of a minority language in translation raises fundamental questions about the activity. These questions relate to the context and limits of translation, the institutional structures of the discipline of translation studies and the persistent misreadings of European cultural history through neglect of its plurilingual nature. Eric Cheyfitz argues for a positive form of alienation where there would be no more master languages, where "all speakers would exist in translation between languages, which is where we all exist" (Cheyfitz, 1991, p. 134). His utopia does exist. It is the daily experience of the speakers of Europe's minority languages. Translation is coterminous with their historical and political experience. Theoretical speculation in these circumstances is not only important for Europeans but for all those on the planet who are 
committed to the protection of the linguistic diversity that underpins our cultural ecosystem.

Michael Cronin: School of Applied Languages, Dublin City University, Dublin 9, Ireland.

\section{References}

BOLGER, Dermot, ed. (1987). The Bright Wave: An Tonn Gheal. Dublin, Raven Arts Press.

CASSIDY, Laurence (1988). "The Arts Council Translation Policy," Translation Ireland, II(4), pp. 8-9.

CHEYFITZ, Eric (1991). The Poetics of Imperialism: Translation and Colonization from The Tempest to Tarzan. Oxford, Oxford University Press.

CRONIN, Michael (1990). "After Fénius Farsaidh: Aspects of Translation in Modern Ireland," Teanga, 10, pp. 109-121.

(1993). "The Irish Language. Past and Present," Van Taal tot Taal, XXXVII(2), pp. 80-83.

(1993b). "Translating Technology. Languages in the Reticular Economy," Teaglaim, 1, pp. 16-18.

CRONIN, Michael, Liam MAC CÓIL and Jurgen SCHNEIDER (1990). Literature without Frontiers: Irish Literary Translation in the European Context. Report presented to the Arts Council and Roinn na Gaeltachta. Dublin, 1990.

DE FRÉINE, Seán (1968). The Great Silence. Cork, Mercier Press.

FITZMAURICE, Gabriel and Declan KIBERD (1991). An Crann Faoi Bhláth: The Flowering Tree. 
JACQUEMOND, Richard (1992). "Translation and Cultural Hegemony: The Case of French-Arabic Translation," pp. 139-158 in Lawrence Venuti, ed., Rethinking Translation. London, Routledge.

JENKINSON, Biddy (1991), "A Letter to an Editor," Irish University Review, $\mathrm{XXI}(1)$, pp. 27-34.

KALLEN, Jeffrey (1993). "Language Maintenance, Loss, and Ethnicity in the United States: Perspectives on Irish," Teanga, 13, pp. $100-114$.

KINSELLA, Thomas and Ó TUAMA, Seán (1981). An Duanaire: Poems of the Dispossessed. Mountrath, Dolmen.

LEERSSEN, Joseph (1986). Mere Irish and Fior Ghael: Studies in the Idea of Irish Nationality, its Development and Literary Expression prior to the Nineteenth Century. Amsterdam, John Benjamins.

MAC NIOCLÁIS, Máirtín (1991). Seán Ó Ruadháin Saol agus Saothar. Dublin, An Clóchomhar.

NIRANJANA, Tejaswini (1992). Siting Translation: History, PostStructuralism and the Colonial Context. Berkeley, University of California Press.

O CEARNAIGH, Seán (1993). "Thoughts on Translation: Round Table Debate with Tomás Mac Síomóin, Alan Titley and Mícheál Ó Cróinín," Poetry Ireland Review, 39, pp. 61-71.

Ó CIOSÁIN, Éamon (1990). "Turning the Tables," Graph, 9, pp. 23-27.

Ó HÁINLE, Cathal (1982). "Towards the Revival. Some Translations of Irish Poetry: 1789-1897," pp. 37-58 in Peter Connolly, ed. Literature and the Changing Ireland. Bucks., Colin Smythe. 
O'LEARY, Peter (1929). Papers on Irish Idiom. Dublin, Browne and Nolan.

Ó MUIRÍ, Pól (1993). "A Desire to Scavenge," Fortnight, 316, pp. 15-17.

Ó SÉAGHDHA, Barra (1993). "The Tasks of the Translator," The Irish Review, 14, pp. 143-147.

SEYMOUR, St. John D. (1929). Anglo-Irish Literature 1200-1582. Cambridge, Cambridge University Press.

SIMON, Sherry (1992). "The Language of Cultural Difference: Figures of Alterity in Canadian Translation," pp. 159-176 in Lawrence Venuti, ed., Rethinking Translation. London, Routledge.

WILDEN, Anthony (1980). The Imaginary Canadian. Toronto, Pulp Press.

ABSTRACT: Altered States: Translation and Minority Languages - The linguistic complexity of Europe is often ignored in political accounts of its translation practice. In particular, the historical experience and contemporary fate of European minority languages are overlooked in assessing the translation strategies available to speakers of minority languages. The problem partly results from a failure to think creatively about definitions of minority languages in a translation context. This context includes the dimension of new technologies which may lead to a new reclassification of languages in Europe and elsewhere. The role of translation in the case of one European minority language, Irish Gaelic, is considered in terms of the dilemmas faced by lesser used languages. Translation is both welcomed and feared. The options available to translators in minority languages differ crucially from those on offer to translators in majority languages. These differences need to be reflected in the theoretical discourse on translation in minority languages but this is not often the case. Furthermore, translation studies as a discipline rarely reflects on its own majority 
language bias, embedded in the structures of the disciplinary dissemination of knowledge. Minority languages are not only essential to a diversity that sustains the fragile ecosystem of human culture but they also raise questions that lie at the heart of translation studies as an area of intellectual inquiry.

\section{RÉSUMÉ: «États altérés»: traduction et langues minoritaires -}

La complexité linguistique de l'Europe est souvent passée sous silence dans les commentaires politiques sur les activités en traduction. En particulier, on fait abstraction de l'expérience historique et du destin contemporain des langues minoritaires d'Europe quand on évalue quelles sont les stratégies de traduction à la disposition des locuteurs de ces langues minoritaires. Le problème provient en partie de ce que l'on ne pense pas à définir de façon créative les langues minoritaires dans un contexte de traduction. Ce contexte comprend la dimension des nouvelles technologies qui peuvent aboutir à un nouveau classement des langues, en Europe et ailleurs. Le rôle de la traduction dans le cas d'une langue minoritaire d'Europe, le gaélique irlandais, est abordé sous l'angle des dilemmes auxquels font face les langues moins utilisées. La traduction est à la fois bienvenue et crainte. Les choix qui s'offrent aux traducteurs de langues minoritaires diffèrent considérablement de ceux qui s'offrent aux traducteurs de langues majoritaires. Il importe d'accorder une attention plus grande qu'actuellement à ces différences dans le discours théoriques sur la traduction des langues minoritaires. En outre, la traductologie en tant que discipline ne réfléchit que rarement sur les préjugés de sa propre langue majoritaire intégrée aux structures de diffusion disciplinaires du savoir. Non seulement les langues minoritaires sont essentielles à la diversité sur laquelle repose le fragile écosystème de la culture humaine mais elles soulèvent des questions qui sont au cœur de la traductologie en tant que domaine de recherche. 